\title{
含硫酸ジルコニア微結晶の生成プロセスと結晶成長
}

\author{
李春廷・山井䉷・加藤 悦朗 \\ (名古屋工業大学工学部, 466 名古屋市昭和区御器所町)
}

\section{Formation Process and Crystal Growth of Zirconium Oxide Sulfate Crystals}

\author{
Chunting LI, Iwao YAMAI and Etsuro KATO \\ (Faculty of Engineering, Nagoya Institute of Technology, Gokiso-cho, Showa-ku, Nagoya-shi \\ 466)
}

\begin{abstract}
Zirconium sulfate solutions were hydrothermally treated at temperatures from $200^{\circ}$ to $250^{\circ} \mathrm{C}$ for various periods of time. Crystalline phases, morphology and amount of solid products were investigated to study, especially, the formation process of zirconium oxide sulfate ( $\mathrm{ZOS}$ ), being submicron thin hexagonal crystals with a chemical composition of $\mathrm{Zr}_{3} \mathrm{O}_{5} \mathrm{SO}_{4} \cdot \mathrm{nH}_{2} \mathrm{O}$. Crystalline phases of the solid products varied with $\mathrm{H}_{2} \mathrm{SO}_{4}$ concentration of the solution; at $240^{\circ} \mathrm{C}$ for 3 days, $m-\mathrm{ZrO} \mathrm{O}_{2}$ and $\mathrm{t}$ $\mathrm{ZrO}_{2}, \mathrm{ZOS}$ and/or a pseudo-ZOS phase (PZOS) and $\mathrm{ZrOSO}_{4} \cdot \mathrm{H}_{2} \mathrm{O}$ at $\mathrm{H}_{2} \mathrm{SO}_{4}$ concentrations below 0.2 mol/l, in the range of $0.2-2.0 \mathrm{~mol} / \mathrm{l}$ and above $2.5 \mathrm{~mol} / \mathrm{l}$ respectively. PZOS formed generally at lower temperature or at the early stage of the hydrothermal process, and its amount decreased with increasing $\mathrm{H}_{2} \mathrm{SO}_{4}$ concentration. Since the PZOS phase was metastable at higher temperature or higher $\mathrm{H}_{2} \mathrm{SO}_{4}$ concentration, it gradually changed to $\mathrm{ZOS}$ with a prolonged hydrothermal treatment time. The ZOS crystals were considered to be formed by a neucleation and crystal growth process. The crystal size of the $\mathrm{ZOS}$ increased with increasing $\mathrm{H}_{2} \mathrm{SO}_{4}$ concentration but was almost independent of $\mathrm{Zr}$ concentration. Effect of seeding and repeated treating on the crystal growth of ZOS was confirmed in a solution containing $1.6 \mathrm{~mol} / \mathrm{l} \mathrm{H}_{2} \mathrm{SO}_{4}$ at $250^{\circ} \mathrm{C}$.
\end{abstract}

[Received July 11, 1988; Accepted October 21, 1988]

Key-words : Zirconium oxide sulfate, Hydrothermal, Formation process, Crystal growth, Seed crystals

\section{1. 緒 言}

ジルコニウム塩の内, $\mathrm{ZrOCl}_{2}, \mathrm{ZrO}\left(\mathrm{NO}_{3}\right)_{2}$ の水溶液は, 加熱処理により $\mathrm{ZrO}_{2}$ 微粒子が生成し ${ }^{1)-3)}$, その生成速 度，形，大きさなどに及ぼす加水分解条件の影響4)，鉱 化剂 ${ }^{(5)}$ ，共存イオン ${ }^{7)}$ の効果などについて既に報告さ れている. しかし, $\mathrm{Zr}\left(\mathrm{SO}_{4}\right)_{2}$ 水溶液については, その 加水分解に関し, $100^{\circ} \mathrm{C}$ 以下の低い温度では硫酸根を含 む非晶質のジルコニウム塩基性塩が生成し，それを熱分 解することにより $\mathrm{ZrO}_{2}$ 微粒子が得られることが知られ ている ${ }^{8)-9)}$ ものの, $100^{\circ} \mathrm{C}$ 以上の温度での加水分解物, 熱処理生成物及びそれらのセラミックスへの応用等につ いて調べたのは著者らの報告以外にはほとんど見あたら ない.

著者らは $\mathrm{Zr}\left(\mathrm{SO}_{4}\right)_{2}$ の水溶液を $200^{\circ} \mathrm{C}$ 以上で水熱処理 することにより, $\mathrm{ZrO}_{2}$ 含有率の高い, $\mathrm{Zr}_{3} \mathrm{O}_{5} \mathrm{SO}_{4} \cdot n \mathrm{H}_{2} \mathrm{O}$ 組成を持つ含硫酸化合物，いわゆる含硫酸ジルコニア微 結晶（以下ZOS と記す）を合成した ${ }^{10)}$. ZOS 微結晶は アスペクト比の大きい板状粒子であり，陽イオン交換性 を示し, 薄板状 $\mathrm{ZrO}_{2}$ の先駆体又は無機イオン交換剤之 しての応用が期待される ${ }^{11)}$. 著者らはまた，このZOS 微結晶をアルカリ水溶液による処理, 又は $\mathrm{Ca}(\mathrm{OH})_{2}$ と 共沈後熱処理することにより, 単斜ジルコニア又は $\mathrm{CaO}$ 安定化立方ジルコニアの板状微結晶を合成できる ことを報告し ${ }^{11)}$ 12), 更に, ZOS 微結晶の性質, $\mathrm{ZrO}_{2}$
八変化するときの方位関係等を基礎に, その結晶構造を 検討した結果, ZOS は $a_{0}=0.631_{1} \mathrm{~nm}, c_{0}=1.0250 \mathrm{~nm}$ の六方晶系であり, その基本構造は立方晶 $\mathrm{ZrO}_{2}$ と密接 な関連があることを明らかにした13).しかし，ZOSの 生成条件, 生成プロセス及び生成機構などに関し, まだ 不明な点が多い. 本研究では, $200^{\circ} \sim 250^{\circ} \mathrm{C}$ におる $\mathrm{Zr}\left(\mathrm{SO}_{4}\right)_{2}$ 水溶液からの生成物の種類, 生成条件などを 調べ, 特にZOS 微結晶の生成プロセス, 結晶成長につ いて考察した。

\section{2. 実験方法}

\section{1 試料の調製}

炭酸ジルコニル $\left(\mathrm{ZrOCO}_{3} \cdot \mathrm{H}_{2} \mathrm{O}\right.$, 第一希元素) を所定 量の $6 \mathrm{~N}$ 濃度に調節した $\mathrm{H}_{2} \mathrm{SO}_{4}$ 水溶液中に攪拌しなが ら溶解し, 溶液がほぼ透明になった後, 蒸留水を加え, 所定の濃度にした。以下, 溶液組成を $\mathrm{Zr}^{4+}$ イオン及び $\mathrm{H}_{2} \mathrm{SO}_{4}$ の濃度を用いて次のように, 例えば, $\mathrm{Zr}^{4+} 0.1$ $\mathrm{mol} / 1, \mathrm{H}_{2} \mathrm{SO}_{4} 0.2 \mathrm{~mol} / \mathrm{l}$ の場合, $\mathrm{ZS}(0.1 / 0.2)$ として, 表示する。得られた溶液 $15 \mathrm{ml}$ をステンレス製の容器に 納めたテフロン製容器（容積 $25 \mathrm{ml}$ ) に入れ, 密封後, 所定温度に保持した恒温槽内に静置した, 所定時間熱処 理すると白色沈殿が生成するので，これを沪過し，沪液 を生成率の測定に用い, 沃紙上の残査を生成物の試料と した。 


\section{2 測定}

種々の条件における析出物の生成率は, 沃液中の $\mathrm{Zr}$ 量から逆算した。すなわち，沪液に少過剩の $28 \%$ のア ンモニア水を加え, $\mathrm{Zr}$ を水酸化物として沈降させ, 沪 過後, 約 $800^{\circ} \mathrm{C}$ で加熱分解して $\mathrm{ZrO}_{2}$ とした。この $\mathrm{ZrO}_{2}$ の量をそれぞれの熱処理条件における未反応量と し, 出発原料中の $\mathrm{Zr}$ をすべて $\mathrm{ZrO}_{2}$ としたときの量と の差をそれぞれの生成量として, 生成率を $100 \%$ 表示 で求めた。

各処理条件における析出物の同定は粉末 X 線回折 ( CuK $\alpha$, Ni-filter, Geigerflex-Rad $1 \mathrm{~B}$ ，理学電機）に より行った。結晶子径は粉末 X 線回折図形の半価幅之 Scherrer の式 ${ }^{14)}$ から求めた. ZOSの（001）及び（300） ピークの半価幅について Warren の式 ${ }^{14)}$ と $1500^{\circ} \mathrm{C}$ で 2 時間焼成した $\alpha-\mathrm{Al}_{2} \mathrm{O}_{3}$ の半価幅を用いて補正した。生成 物の形態と大きさは透過型電子顕微鏡（日本電子製, JEM-200 A, 加速電圧 $200 \mathrm{kV}$ ) により観察した.

\section{3. 結果と考察}

\section{$3.1 \mathrm{ZOS}$ の生成条件}

$\mathrm{Zr}\left(\mathrm{SO}_{4}\right)_{2}$ の水溶液が薄いときには室温においても加 水分解反応が起こり，白色の沈殿を生成するが，結晶性 生成物は $150^{\circ} \mathrm{C}$ 以上で始めて生成する。水熱処理温度 及び $\mathrm{H}_{2} \mathrm{SO}_{4}$ の濃度条件に従い, 数種の異なる結晶相が 生成した。

$240^{\circ} \mathrm{C}$ で 3 日間熱処理して得られた代表的な結晶性生 成物の X 線回折図形を図 1 に示す. $Z \mathrm{~S}(0.1 / 0.2)$ では, 生成物は単斜 $\mathrm{ZrO}_{2}$ 微結晶粒子（図 1 (a)) であり, $\mathrm{ZS}$ (0.5/1.0) では, ZOS 微結晶（図 1 (c)）が生成した. $\mathrm{ZS}(0.2 / 0.4)$ の組成の生成物のX線回折図形 (図 1 (b)) はZOSのそれと似ているが，回折線がブロードで， ZOS の（001）に相当する低角度のピークが更に低角側 に位置しており, 層間距離が大きいことを示す.しかし, （300）に相当するピークは割合に鋭く，化学分析による 之, 組成も硫酸の含有率がわずかに大きいだけで, ZOS に非常に近かったので，この生成物は層面方向で はZOS とほとんど同一であるが，層間の開いた $c$ 軸方 向に秩序性の低いZOS 類似物と思われる。以下この生 成物をZOS と区別して PZOS と記す. $\mathrm{H}_{2} \mathrm{SO}_{4}$ 濃度が $2.5 \mathrm{M}$ 以上になると, ZOS と全く別種の，肉眼でも観 察できるほどの大きさ数百 $\mu \mathrm{m}$ の単結晶粒子が生成し, 化学分析によれば, これは $\mathrm{ZrOSO}_{4} \cdot \mathrm{H}_{2} \mathrm{O}$ に相当する化 学組成を持つ. そのX線回折ピークは極めて多く鋭いた め, 図 $1(\mathrm{~d})$ ではその観察ピークの強度のみを示した。

$\mathrm{ZrOCO}_{3}$ と $\mathrm{H}_{2} \mathrm{SO}_{4}$ との混合比を $1: 2$ と一定にし，濃 度および処理温度を変えて, 3 日間の水熱処理を行った 場合の, 温度及び濃度に対する生成物の関係は図 2 に示 すようである. $\mathrm{H}_{2} \mathrm{SO}_{4}$ 濃度が低いときの領域 I では,

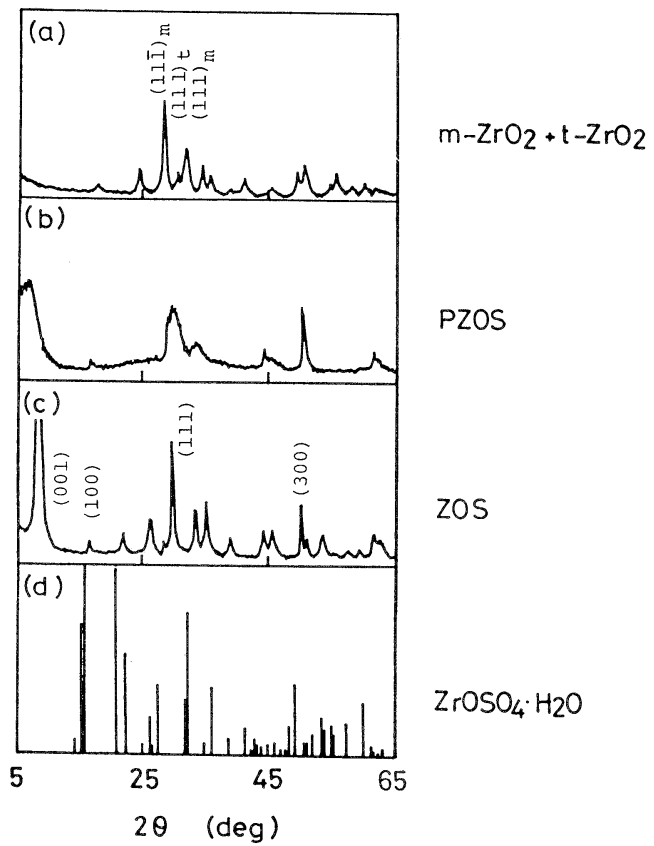

Fig. 1. Observed X-ray diffraction patterns of products obtained at $240^{\circ} \mathrm{C}$ for 3 days from $\mathrm{Zr}\left(\mathrm{SO}_{4}\right)_{2}$ solutions. (a) ZS (0.1/0.2), (b) ZS(0.2/0.4), (c) ZS (0.5/1.0), (d) $\mathrm{ZS}(1.5 / 3.0)$

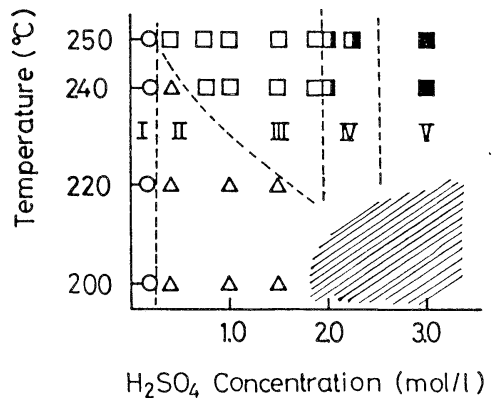

Fig. 2. Crystalline phases obtained by hydrothermal treatment of $\mathrm{Zr}\left(\mathrm{SO}_{4}\right)_{2}$ solutions at various temperatures for 3 days.

$\bigcirc \mathrm{m} \cdot \mathrm{ZrO}_{2}+\mathrm{t}-\mathrm{ZrO}_{2}, \triangle \mathrm{PZOS}, \square \mathrm{ZOS}$,

$\mathrm{ZrOSO}_{4} \cdot \mathrm{H}_{2} \mathrm{O}, \mathrm{ZOS}+\mathrm{ZrOSO}_{4} \cdot \mathrm{H}_{2} \mathrm{O}$

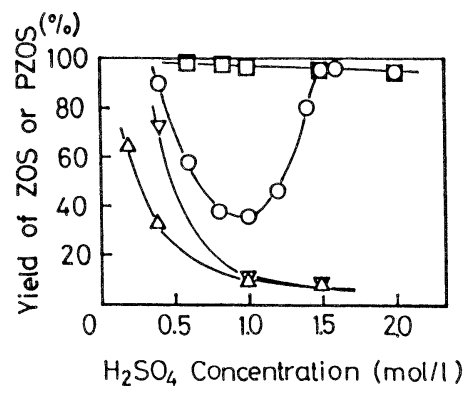

Fig. 3. Yield of ZOS or PZOS by hydrothermal treatment of $\mathrm{Zr}\left(\mathrm{SO}_{4}\right)_{2}$ solutions for 3 days. $\triangle 200^{\circ} \mathrm{C}, \nabla 220^{\circ} \mathrm{C}, \bigcirc 240^{\circ} \mathrm{C}, \square 250^{\circ} \mathrm{C}$ 
生成物は単斜晶 $\mathrm{ZrO}_{2}$ 又は単斜晶 $\mathrm{ZrO}_{2}+$ 正方晶 $\mathrm{ZrO}_{2}$ 微 粒子であり, 領域 IIIではPZOS が生成した。領域III $\mathrm{ZOS}$ 微結晶の生成, 領域 $\mathrm{V}$ は $\mathrm{ZrOSO}_{4} \cdot \mathrm{H}_{2} \mathrm{O}$ 単結晶粒子

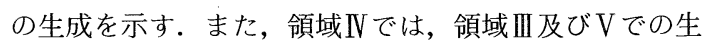
成物の混合物が得られ, 斜線領域からは生成相は認めら れなかった。

$\mathrm{ZrOCO}_{3}$ と $\mathrm{H}_{2} \mathrm{SO}_{4}$ の比を $1: 2$ とし, 濃度の異なる各 溶液を $200^{\circ}, 220^{\circ}, 240^{\circ}$ 及び $250^{\circ} \mathrm{C}, 3$ 日間の水熱処理 を行った場合での生成率と濃度の関係を図 3 に示す. $200^{\circ} \mathrm{C}$ では, 生成率は $\mathrm{H}_{2} \mathrm{SO}_{4}$ 濃度の増大とともに低く なり, $\mathrm{H}_{2} \mathrm{SO}_{4}$ 濃度が $2.0 \mathrm{M}$ 以上では 3 日間の水熱処理 で，生成物は認められず，処理液はほとんど透明なもの であった. $250^{\circ} \mathrm{C}$ において, 各組成とも, 生成はほぼ完 了し，100\%近い生成率を示した。しかしながら， $240^{\circ} \mathrm{C}$ では, 両側の $\mathrm{H}_{2} \mathrm{SO}_{4}$ 濃度組成で $100 \%$ 近い生成 率を示したのに対し， $\mathrm{H}_{2} \mathrm{SO}_{4}$ 濃度 $1.0 \mathrm{M}$ 組成では，生 成率はわずか $40 \%$ 程度であり, 凹形の曲線となってい ることが注目される。

\subsection{ZOS 微結晶の生成プロセス}

\section{（1）生成率の時間的变化}

図 3 に示す $240^{\circ} \mathrm{C}$ での生成率曲線は興味深いもので, 溶液組成に対する生成挙動の違いについて調べる必要が ある。 ZS $(0.2 / 0.4) ; Z S(0.5 / 1.0)$ 及び ZS $(0.75 / 1.5)$ の三つの代表的な溶液組成の各温度での生成率の時間的 変化を図 4 の (a)，（b）及び (c) に示す.

ZS $(0.2 / 0.4)$ の組成（a) では，いずれの温度におい ても反応は初期に非常に速 $<, 200^{\circ}, 220^{\circ} \mathrm{C}$ では，十数 時間以内に反応は定常状態に近くなり, それ以後生成率 は非常にゆっくりしか増加しなかった。この定常状態に 近い生成率は温度の関数であり, $240^{\circ} \mathrm{C}$ 以上の水熱温度 では反応は短時間で完了した．ZS (0.5/1.0) の溶液組 成（b) では， $220^{\circ} \mathrm{C}$ 以下の温度では反応が進まず， 3 日でも生成率はわずか数パーセントであった．図 4 (a) と異なり，更に高い温度においても，生成率は時間とと もにおおよそ直線的に増加する. ZS $(0.75 / 1.5)$ 組成 (c) では， $220^{\circ} \mathrm{C}$ 以下では，(b) の場合とよく似ており，生 成率はさらにわずかであったが, $240^{\circ}, 250^{\circ} \mathrm{C}$ の水熱温 度では, 最初の数時間で生成率が低いものの, それから 生成率は急激に増大して S 字曲線を示し，1日程度で生 成率が $100 \%$ 近くに達した。なお，生成率の時間的変 化が図の (a)，(b)，(c) いずれの型となるかは，主と して溶液中の $\mathrm{H}_{2} \mathrm{SO}_{4}$ 濃度に依存し, $\mathrm{ZrOCO}_{3}$ の含有率 にほとんど依存しない，一例として，図 4 (c) に示す ように, ZS $(0.5 / 1.5)$ 組成の生成率変化は ZS $(0.75 / 1.5)$ 組成之ほぼ同じで，ZS $(0.5 / 1.0)$ 組成之は全く異なっ ている.

\section{（2）生成物形態の時間的変化}

$200^{\circ} \mathrm{C}$ では溶液濃度に関係なく, 生成物は極めて薄い

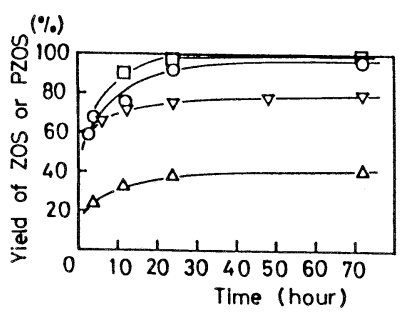

(a) $\mathrm{ZS}(0.210 .4)$

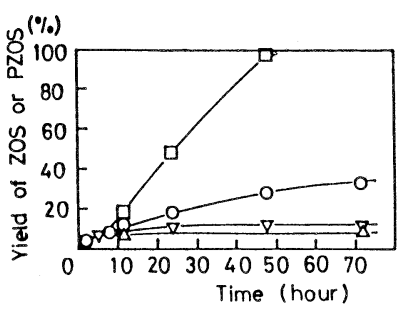

(b) $\mathrm{ZS}(0.5 / 1.0)$

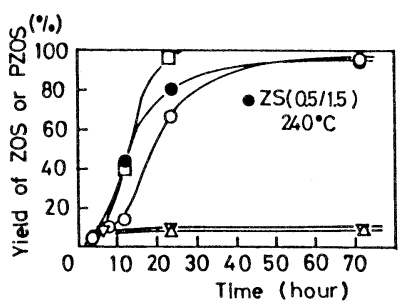

(c) $\mathrm{ZS}(0.75 / 1.5)$

Fig. 4. Yield of ZOS or PZOS with hydrothermally treated time.

$\triangle 200^{\circ} \mathrm{C}, \nabla 220^{\circ} \mathrm{C}, \bigcirc 240^{\circ} \mathrm{C}, \square 250^{\circ} \mathrm{C}$

フレーク状微結晶の凝集物であり, X 線的には PZOS に相当していた。 この温度では, 溶液中の $\mathrm{H}_{2} \mathrm{SO}_{4}$ 濃度 が $1.0 \mathrm{M}$ 以上になると, 生成物中に始めて六角形をし たZOS 微粒子が認められた.

$\mathrm{ZS}(0.2 / 0.4) ; \mathrm{ZS}(0.5 / 1.0)$ 及び ZS $(0.75 / 1.5)$ の 三つの代表的な溶液組成からの, $240^{\circ} \mathrm{C} に お け る$ 水熱処 理時間を変えた場合の, 生成物の電子顕微鏡写真を図 5 に示す。短時間 (4 時間) では, 粒子形態はいずれも $\mathrm{PZOS}$ の特徵を持ち, 極めて薄いフレーク状の凝集体 である。しかし, 高濃度条件 ZS (0.75/1.5) では, 図 4

(c)，に示すようにその生成量は極めて少なく, 六角板 状微結晶の混在も認められた。

時間が長くなるにつれて，ZS (0.2/0.4) では，生成 相の形態にはほとんど変化がないが，3 日での生成物に は少量の板状孤立粒子 (ZOS) が存在する。しかし, ZS $(0.5 / 1.0)$ 組成では，12 時間でかなりの量の板状孤 立粒子が存在し，3 日の生成物はほとんど板状粒子から なっている. $\mathrm{H}_{2} \mathrm{SO}_{4}$ 濃度の更に高い $\mathrm{ZS}(0.75 / 1.5)$ の 組成では，12 時間の生成物は既にほとんど板状粒子か らなっており，3 日の生成物はすべて六角板状 ZOS 粒 

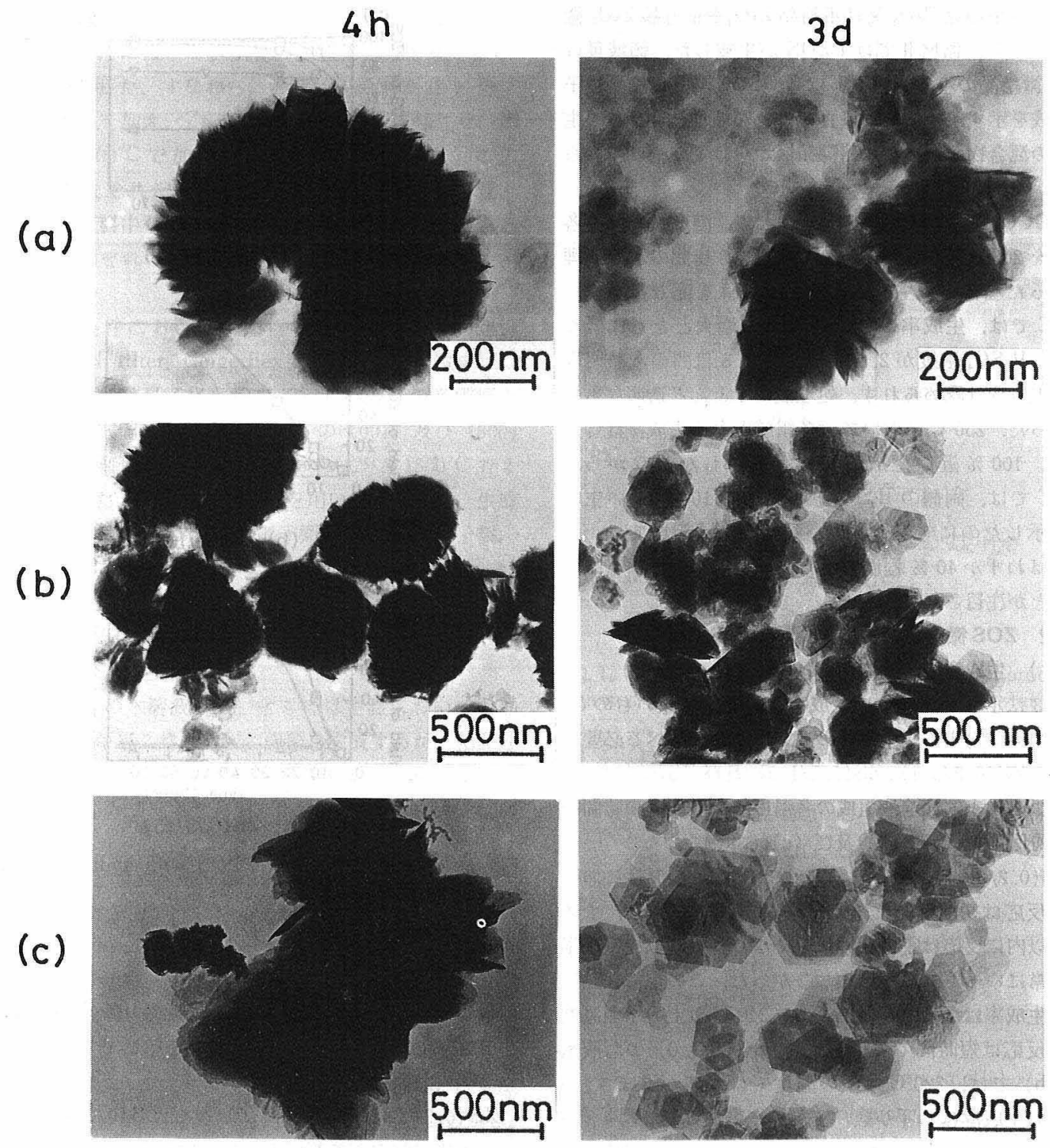

Fig. 5. TEM photographs of products obtained at $240^{\circ} \mathrm{C}$ for $4 \mathrm{~h}$ and for 3 days. (a) $\mathrm{ZS}(0.2 / 0.4)$, (b) $\mathrm{ZS}(0.5 / 1.0)$, (c) $Z \mathrm{~S}(0.75 / 1.5)$.

子である.

図 6 に $240^{\circ} \mathrm{C}$ における上記の結果を模式的に示す. 各溶液組成から，最初にPZOS が生成し，ある程度時 間が経つと，孤立板状 ZOS 粒子が生成する。この時間 は $\mathrm{H}_{2} \mathrm{SO}_{4}$ 濃度が高いほど短く, 更に処理時間が長くな ると，ZOS 板状粒子の割合が大きくなり，最終的にす ベて六角板状粒子になる.

図 6 と比較すると, 図 4 (a) 及び図 4 (b), (c) の短 時間生成物はPZOS に対応し，図 4 (b) 特に (c) の 十数時間以後は六角板状 ZOS 粒子の生成及び成長に対 応することが分かる。

PZOS は生成過程の初期において急激な加水分解反
応によって生成し，この生成は恐らく溶液中のイオン錯 体との構造上の類似性に関連すると思われる. 一般に 4 価金属塩の加水分解は酸の低濃度化によって促進される ことが知られており7, PZOS の生成も処理温度が高い ほよ゙, $\mathrm{H}_{2} \mathrm{SO}_{4}$ 濃度が低いほど, 高い生成率を示し, $\mathrm{H}_{2} \mathrm{SO}_{4}$ 濃度 $0.4 \mathrm{M}$ 組成の $240^{\circ} \mathrm{C}$ 以上の処理温度では, ほほ $100 \%$ 近くに達してしまう。しかしながらこの $\mathrm{PZOS}$ は $\mathrm{H}_{2} \mathrm{SO}_{4}$ 溶液中で完全に安定ではなく, 長時間 の水熱処理後には孤立板状の ZOS 微結晶に変化する.

高い $\mathrm{H}_{2} \mathrm{SO}_{4}$ 濃度条件での六角板状 ZOS 微結晶は図 5 (c) のS字曲線からも分かるように溶液からいわゆる 核形成一成長機構により生成すると考えられる．温度， 


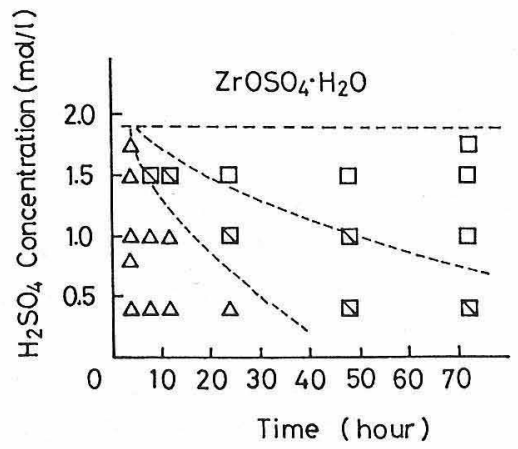

Fig.6. Crystalline phases obtained from different $\mathrm{Zr}$ $\left(\mathrm{SO}_{4}\right)_{2}$ solutions with hydrothermal time at $240^{\circ} \mathrm{C}$. $\triangle \mathrm{PZOS}, \square \mathrm{ZOS}, \triangle \mathrm{PZOS}+\mathrm{ZOS}$.

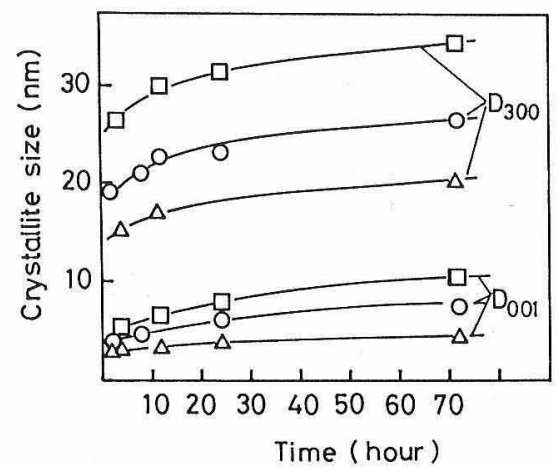

Fig. 7. Apparent crystallite size of ZOS or PZOS obtained at $240^{\circ} \mathrm{C}$ with hydrothermally treated time. $\triangle \mathrm{ZS}(0.2 / 0.4), \bigcirc \mathrm{ZS}(0.5 / 1.0), \square \mathrm{ZS}(0.75 / 1.5)$

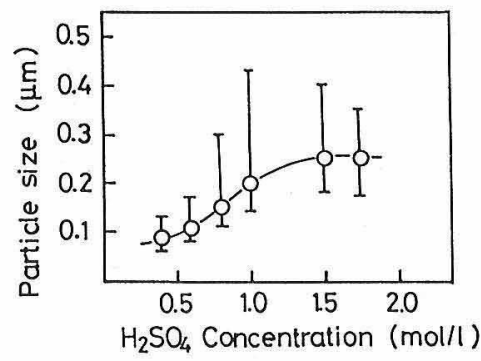

Fig. 8. Dependence of average particle sizes of ZOS crystals obtained at $250^{\circ} \mathrm{C}$ for 3 days on $\mathrm{H}_{2} \mathrm{SO}_{4}$ concentration.

$\mathrm{H}_{2} \mathrm{SO}_{4}$ 濃度が高いほど, 結晶成長速度が大きいことは 微結晶 $\mathrm{ZOS}$ の溶解度が温度や $\mathrm{H}_{2} \mathrm{SO}_{4}$ 濃度が高いほど大 きいことに関連すると思われる。

\section{3 結晶成長及び種結晶の効果}

生成物のX線回折図形は, 短時間では図 1 (b) に示 したように非常にブロードであるが好理時間とともに回 折線が鋭くなる．X線回折図の（300）及び（100）ピー クの半価幅から测定された板の面及び厚み方向の見掛け の結晶子径の処理時間に伴う変化を図 7 に示す. いずれ
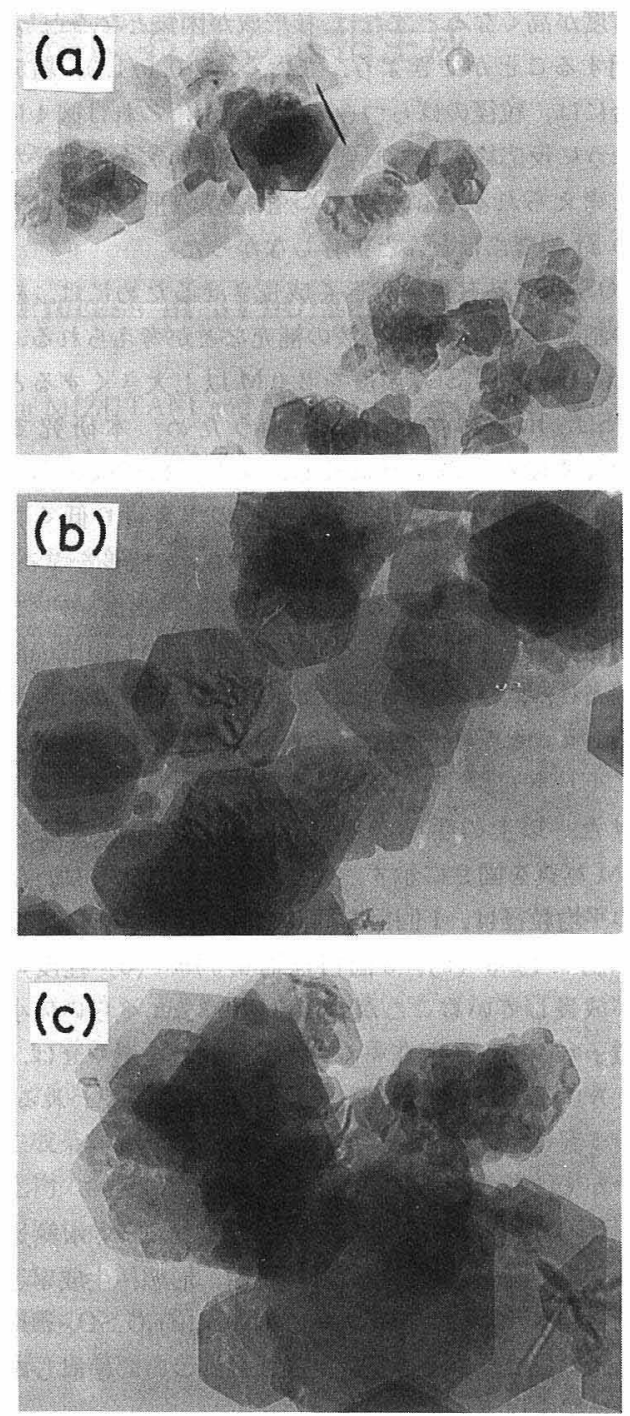

$500 \mathrm{~nm}$

Fig. 9. TEM photographs of ZOS crystals showing effect of seed crystals on crystal growth.

(a) as synthesized $\left(\mathrm{ZS}(0.6 / 1.75), 250^{\circ} \mathrm{C}, 3\right.$ days $)$,

(b) repeat growth, 2 times,

(c) repeat growth, 3 times.

の方向についても， $\mathrm{H}_{2} \mathrm{SO}_{4}$ 濃度が高いほど, 結晶子径 が大きく，結晶性の高いことを示す。

$250^{\circ} \mathrm{C}, 3$ 日間処理後における粒径亡溶液中の $\mathrm{H}_{2} \mathrm{SO}_{4}$ 濃度との関係を図 8 に示す. PZOS を経由するZS (0.2/0.4) 組成での生成 ZOS 微結晶は約 $0.1 \mu \mathrm{m}$ 程度 で, $\mathrm{H}_{2} \mathrm{SO}_{4}$ 濃度の増大に伴い, 平均粒径が大きくなり, $1.5 \mathrm{M}$ 以上では $0.25 \mu \mathrm{m}$ 程度になっている.このこと は, $\mathrm{H}_{2} \mathrm{SO}_{4}$ 濃度が大きくなるにつれて, PZOS の生成 量の少ないこと，また，前述したようにZOS 微結晶の 
溶解度が高くなるとすれば,核形成が困難となるとして, 説明することができよう。また，ZS $(0.5 / 1.0)$ 組成の 場合には，粒径のばらつきが大きいが，これは図 4 に示 すように反応終了まで必要な時間が長いことに関係があ ると考えられる. なお, ZOS 微結晶の平均粒径は溶液 中の Zr 濃度にほとんど依存しなかった。

ZOS 微結晶を更に大きく成長させるためには, 核形 成の制御あるいは反応母液の補充などが考えられる. し かしながら, $\mathrm{H}_{2} \mathrm{SO}_{4}$ 濃度を $2.0 \mathrm{M}$ 以上大きくすると, $\mathrm{ZrOSO}_{4} \cdot \mathrm{H}_{2} \mathrm{O}$ が生成してしまうため, 本研究では $\mathrm{H}_{2} \mathrm{SO}_{4}$ 濃度をそれより低くし，また，核形成を抑える ため, Zr 濃度を ZS (0.85/1.75) の場合より低くした $\mathrm{ZS}(0.6 / 1.75)$ 組成において種結晶による成長を試みた.

$\mathrm{ZS}(0.6 / 1.75)$ 組成の溶液を $250^{\circ} \mathrm{C}, 2$ 日間熱処理し， 生成物の $1 / 5$ を取り出して種結晶とし, 同じ組成の溶液 を補充し, 同様に熱処理した. 種結晶が溶液からの沈降 分離することを防ぐため, 試料容器を恒温槽内の回転装 置にセットし，非常にゆっくり $(2 \mathrm{rpm})$ で回転し攪汼 させた. 以上の手順を繰り返して得られた生成物の TEM 写真を図 9 に示す. 図から明らかなように, 生成 物の平均粒径は, 1 回目の約 $0.25 \mu \mathrm{m}$ (a) に対し, 2 回 目は約 $0.4 \mu \mathrm{m}$ (b), 3 回目は約 $0.6 \mu \mathrm{m}$ (c) 程度に粒 子が成長していることが分かる。 $0.3 \mu \mathrm{m}$ ぐらいの小さ い粒子もいくらか混在するが，成長回数を増やせば，更 に大きいZOS 微結晶の合成も可能であると思われる.

\section{4. 総 括}

$\mathrm{Zr}\left(\mathrm{SO}_{4}\right)_{2}$ の水溶液を, $200^{\circ} \sim 250^{\circ}$ において水熱処理 した. 処理時間に伴う生成物の種類, 形態, 生成率等の 変化を調へ，含硫酸ジルコニア $\left(\mathrm{ZOS}, \mathrm{Zr}_{3} \mathrm{O}_{5} \mathrm{SO}_{4} \cdot n \mathrm{H}_{2} \mathrm{O}\right)$ 微結晶の生成プロセス及び結晶成長について検討した. その結果を以下にまとめる.

(1) $\mathrm{Zr}\left(\mathrm{SO}_{4}\right)_{2}$ 水溶液の組成及び水熱処理条件に従 い, $\mathrm{ZrO}_{2}$ 微粒子, $\mathrm{ZOS}$ 微結晶, 結晶性の低い $\mathrm{ZOS}$ 類 似相 (PZOS と記す) 及び $\mathrm{ZrOSO}_{4} \cdot \mathrm{H}_{2} \mathrm{O}$ 単結晶粒子が 生成するので, それぞれの生成領域を明らかにした。

（2）PZOS は低温又は反応の初期で加水分解反応 により生成し, その生成率は $\mathrm{H}_{2} \mathrm{SO}_{4}$ 濃度の減少ととも
に増大する。

( 3 ） PZOS は更に高い温度又は高い $\mathrm{H}_{2} \mathrm{SO}_{4}$ 濃度で は準安定であり，時間とともに六角板状 ZOS 微結晶へ と変化する.

(4) ZOS 微結晶は核形成-成長機構によって生成す ると思われ，生成微結晶の粒径は溶液中の $\mathrm{H}_{2} \mathrm{SO}_{4}$ の濃 度が高くなるにつれて大きくなるが，溶液中の $\mathrm{Zr}$ 濃度 にはほとんど依存しない。

（5）種結晶を導入することにより，より大きい粒径 を持つZOS 微結晶が得られた。水熱条件, 溶液組成, 種の量, 種結晶による成長の繰り返し回数等を制御する ことにより，ZOS 微結晶を更に成長させることができ る.

\section{文献}

1) A. Clearfield, Inorg. Chem., 3, 146-48 (1964).

2) C. B. Alexander and J. Bugosh, U. S. Pat. , 2, 984, 628 (1961).

3) 村瀬嘉夫, 加藤悦朗, 日化, 1976, 425-30 (1976).

4）村瀬嘉夫，加藤悦朗，平野正典，穼協， 92, 64-70 (1984).

5) H. Nishizawa, N. Yamazaki, K. Matsuoka and H. Mitsushio, J. Am. Ceram. Soc., 65, 343-46 (1982).

6) E. Tani, M. Yoshimura and S. Sōmiya, J. Am. Ceram. Soc., 66, 11-14 (1983).

7）加藤悦朗, 江副正信, 近藤正保, 村瀬嘉夫, 的場香磁, 窯協, 95, 984-90 (1987).

8）阿部秀来, 村島弘明, 岡 紀六, 戸石光輝, 公開特許公 報 $(\mathrm{A})$, 昭 59-111922 (1984).

9) A. A. Grizik, L. G. Nechamkin, I. F. Poletayev and M.N. Butova, The Third International Conference on Science and Technology of Zirconia, Tokyo, September (1986).

10）李 春廷, 加藤悦朗, 大門啓志, 村瀬嘉夫, 䇺協, 95, 509-14 (1987).

11) E. Kato, C. -T. Li and Y. Murase, The Third International Conference on Science and Technology of Zirconia, Tokyo, September (1986).

12) E. Kato and C. T. Li, International Symposium \& Exhibition on Science and Technology of Sintering, Tokyo, November (1987).

13）李 春廷, 大門啓志, 村瀬嘉夫, 加藤悦朗, セラミック 論文誌, 96, 980-84 (1988).

14) H.P. Klug and L.E. Alexander, "X-ray Diffraction Procedures", John Wiley \& Sons, Inc., New York (1954). 